\title{
Relationships between physical characteristics of the pig house, the engineering and control systems of the environment, and production parameters of growing pigs
}

\author{
R. GEERS, D. BERCKMANS, V. GOEDSEELS, F. MAES *, \\ J. SOONTJENS * et J. MERTENS * \\ Laboratory for Agricultural Building Research, K.U. Leuven, Kardinaal \\ Mercierlaan 92,B-3030 Heverlee, and * AVEVE-B.B., \\ *Belgian Farmers' Association, Minderbroederstraat 8, B-3000 Leuven, Belgium
}

\begin{abstract}
Summary
In order to explain variations of parameters related to growth, feed conversion ratio and mortality rate of fattening pigs, relationships with building characteristics of the pig houses were investigated. The method of collecting the data from contractual farming conditions (97 pig houses, all-in all-out system) allowed a homogeneous and randomised distribution of other feed efficiency determining factors.

The variations of the mortality rate and the length of the fattening period were explained by the variation of the surface area and the volume of the pig house. Longer fattening periods and higher mortality rates were found in larger pig houses, where larger numbers of animals are present, especially when the heating facilities are inappropriate. The same interaction was found with respect to the relationship of feed conversion ratio and weight gain, correlating with the thermal conductivity of the roof and the walls. A comparable differential effect was found when comparing the ventilation system. Most of the relationships were found within mechanical ventilated pig houses.

The occcurrence of tail biting was partly explained by the varation of the available space for the pigs and the variations of the inside temperature. Whereas a positive correlation coefficient was found between the air velocity at the height of the pigs and the occurrence of growth-retarded animals. The importance of the regulation of the air inlet was indicated. Animals with coughs tended to grow slower, and the carcasses were classified into the lower commercial grades, but again the interaction with the heating and ventilation system was significant. On the other hand, fast growing animals tended to realize a lower feed conversion ratio, but were classified in the high and the low carcass grades as well. As shown by the analysis of the correlation coefficients a significant proportion of the variation of the production parameters was explained by the variation of building characteristics and the environmental engineering and control systems. But in addition to guide-lines concerning environmental conditions, additional suggestions have to be formulated concerning the thermoregulatory behaviour and the prevention of health problems to optimize the pig production process.
\end{abstract}

Key words : engineering, environment, pig house, production, growing pigs. 


\section{Introduction}

From laboratory experiments, specific environmental conditions ( \&.g. temperature, humidity, air velocity, ventilation rate) have been proposed for optimal efficiency of feed utilization of pigs, and for avoiding health problems (KALICH, 1980 ; LINDQuist, 1974 ; Mount, 1968 ; Stolpe \& Bresk, 1969 ; Verstegen, 1971).

The engineering design and the control of the house environment aim to realize those climatic conditions in order to optimize the animal production process. According to the engineering and control possibilities of the environment within the pig house, differences were found in feed conversion ratio, mortality rate and carcass values of growing pigs (Texier et al., 1981 ; GeErs et al., 1984 a, b). Although our method of collecting the data allowed a homogeneous and randomized distribution of other production efficiency determining factors, in order to explain those differences the following hypotheses remain; a) varying interactions between the outside and inside environmental conditions depending on the construction of the pig house (WAHLSTROM, 1981); b) the control of the housing system at the level of stockmanship; c) the physical characteristics of the pig house.

The present paper explores the extent to which the variation in the production characteristics is explained by variations of the building characteristics and/or by the use of the engineering and control systems of the environment. Quantification of these variations allows a classification to be made according to their importance.

\section{Material and methods}

Field data were put at our disposal by the Belgian Farmers' Association. Pig houses were selected after an initial visit in order to equalize and to distribute at random possible factors not linked up with the housing systems involved.

97 pig houses were chosen after visiting about 300 piggeries. For each pig house and in order to be ensured of good stockmanship on the farm, the mean production results during the period 1978-1982 had to be better than the over-all mean. A sufficient number of animals was available (534 fattening periods with 355 pigs as a mean value) to overcome possible influences associated with differences in genotype. All animals within the same period of time received the same commercial feed by means of the same feeding system (ad libitum, but with the possibility to avoid spoilage of the feed by adjusting the level within the feeding-trough). The fattening period was used as a working unit because the pig house could only change between two fattening periods. All pigs were fattened within an all-in all-out system.

Pig houses were classified as follows :

1. Piggeries with compartments (CO) (rooms for 70 to 140 pigs each), separated corridor as air inlet, central heating and mechanical ventilation (available from 1980 onwards number $\mathrm{n}=28$;

2. Piggeries with central heating $(\mathrm{CH})$ : roof-mounted fan $(\mathrm{RF}) \mathrm{n}=9$, covered open ridge $(\mathrm{CR}) \mathrm{n}=8$; 
3. Piggeries with heating unit with fan suspended (FH) : roof-mounted fan (RF) $\mathrm{n}=9$, covered open ridge $(\mathrm{CR}) \mathrm{n}=8$;

4. Piggeries heated by pipes $(P H)$ : roof-mounted fan $(R F) n=9$, covered open ridge $(\mathrm{CR}) \mathrm{n}=6$;

5. Piggeries without heating $(\mathrm{NH}): \mathrm{n}=20$.

Some pig units had only recently joined the contractual system, hence too few production results were available to calculate a representative mean value; hence the results were not used. This explains the number of observations mentioned in Tables 1, 2 and 3. Heating was normally used up to the first 3-4 weeks of the fattening period. For class 2 to 4 all air inlets had a wind baffle, while for class 5 the air inlet and air outlet was not taken into account to become a sufficient number of piggeries.

The following building characteristics were measured : surface area (SA), volume (VO), slat surface (SS), whereas thermal conductivity of walls (TCW) and roof (TRR) were calculated based on the thickness and the type of material. The following parameters were recorded during monthly visits within the investigation period : number of animals present (NA), number of pens with dirty laying area (PL), number of pens with diarrhoea (PD), number of pens with cough (PC), number of pens with growth-retarded animals (PG), number of pens with tail biting (PT), the accessibility of the food (AF), (0: feeding-trough nearly empty; 1 : semi-full ; 2 : full), the interval temperature (IT) (4 measuring points $\pm 1 \mathrm{~m}$ above the floor), the air velocity in the middle of each pen and at the height of the pigs (AV), the regulation of the air inlet flap (RI) (0: unregulated ; 1 : occasionally regulated ; 2 : daily regulation).

Production parameters calculated per fattening period and per group of finishing pigs were : initial and final body weight per pig (IBW), (FBW kg), total weight gain per pig (WG $\mathrm{kg}$ ), length of the fattening period (LFP days), feed intake per pig (FI kg), mortality rate (MR \%), emergency slaughter rate (ESR \%) (pigs which were slaughtered because of accidents, stress, etc.), feed conversion ratio (FCR), carcass values $(\mathrm{CV}$, according to $\mathrm{EEC}$ commercial grade ranked in decreasing order $\mathrm{E}, \mathrm{I}, \mathrm{II}, \mathrm{III}$, IV). In order to relate the building characteristics to the inquiry and production results, both sets of results were calculated as mean values of all the fattening periods involved ( \pm 2.5 periods per year). Table 1 shows the general means with standard deviation of the parameters investigated. Statistical analysis by means of the calculation of the correlation coefficients within a linear model was performed. Non-normal distributions were transformed towards a normal distribution. To ensure a sufficient variability within each variable studied, all data were considered together, and within each pig house classification as well.

\section{Results and discussion}

- Correlation coefficients $(P<0.05)$ between building characteristics and production parameters (mean values per piggery calculated from the fattening periods between 1978 to 1982 ; number of measurements $=$ number of piggeries) (Table 2). 
TABLE 1

Average with standard deviation (s.d.) of the parameters investigated, number of piggeries $=86$.

Moyenne (Mean) avec écart-type (s.d.) des paramètres examinés, nombre de porcheries $=86$.

\begin{tabular}{|c|c|c|c|}
\hline Abbreviation & & Mean & s.d. \\
\hline$\ldots \ldots$ & Surface & 315 & 148 \\
\hline \multirow[t]{3}{*}{$\ldots \ldots$} & Volume $\left(\mathrm{m}^{3}\right)$ & 996 & 490 \\
\hline & Pen surface $\left(\mathrm{m}^{2}\right)$ & 9.0 & 1.42 \\
\hline & Pen sturface per pig $\left(\mathrm{m}^{2}\right)$ & 0.82 & 0.22 \\
\hline$\ldots \ldots$ & Slat surface $\left(\mathrm{m}^{2}\right)$ & 3.90 & 1.42 \\
\hline TCW $\ldots .$. & Thermal conductivity wall $(\mathrm{k})\left(\mathrm{Wm}-2 \mathrm{-} \mathrm{C}^{-1}\right)$ & 1.38 & 0.667 \\
\hline TCR $\ldots$. & Thermal conductivity roof $(\mathrm{k})\left(\mathrm{Wm}-2 \mathrm{C}^{\prime} \mathrm{C}^{-1}\right)$ & 0.60 & 0.446 \\
\hline$\ldots \ldots$ & Inside temperature ("C) & 18.6 & 2.18 \\
\hline AV $\ldots \ldots \ldots$ & Inside air velocity $(\mathrm{cm} / \mathrm{sec})$ & 11.8 & 2.37 \\
\hline RI $\ldots \ldots \ldots$ & Regulation air inlet (*) & 1.01 & 0.742 \\
\hline PC $\ldots \ldots$ & Cough $(\%)$ & 1.19 & 0.836 \\
\hline PG $\ldots \ldots \ldots$ & Growth-retarded $(\%)$ & 1.34 & 1.17 \\
\hline PT $\ldots \ldots \ldots$ & Tail biting $(\%)$ & 2.94 & 3.10 \\
\hline PD $\ldots \ldots$ & Diarrhoea $(\%)$ & 0.847 & 1.98 \\
\hline PL & Dirty laying area $(\%)$ & 15.2 & 13.2 \\
\hline AF $\ldots \ldots \ldots$ & Regulation feed-trough $(*)$ & 0.949 & 0.689 \\
\hline NA & Number of animals & 355 & 216 \\
\hline IBW & Initial body weight $(\mathrm{kg})$ & 20.8 & 1.06 \\
\hline FBW $\ldots \ldots$ & Final body weight $(\mathrm{kg})$ & 102 & 3.79 \\
\hline FCR $\ldots \ldots$ & Feed conversion ratio & 3.40 & 0.147 \\
\hline LFP . . . . . & Fattening period (days) & 141 & 8.26 \\
\hline ESR & Emergency slaughter rate $(\%)$ & 0.239 & 0.486 \\
\hline MR $\ldots \ldots$ & Mortality rate $(\%)$ & 4.43 & 1.95 \\
\hline \multirow[t]{5}{*}{$\mathrm{CV} \ldots \ldots \ldots$} & Carcass value $\mathrm{E}(\%)$ & 7.16 & 4.06 \\
\hline & I $(\%)$ & 42.7 & 7.02 \\
\hline & II $(\%)$ & 37.9 & 7.31 \\
\hline & III $(\%)$ & 6.71 & 3.60 \\
\hline & IV $(\%)$ & 5.44 & 3.57 \\
\hline WG & Weight gain $(\mathrm{kg})$ & 81.2 & 4.07 \\
\hline FI $\ldots \ldots \ldots$ & Feed intake $(\mathrm{kg})$ & 277 & 13.8 \\
\hline
\end{tabular}

(*) Dimensions see material and methods.

A. Mortality rate, energency slaughter rate and lengt/ of the fattening period

The variations of the mortality rate (MR) and the length of the fattening period (LFP) were statistically and significantly linearly related to the variation of the surface area (SA) and the volume (VO) of the pig house as well. Although optimal house dimensions per pig were proposed (FARGE et al., 1981; LINDQuisT, 1974) 
irrespective of labour input, we found them to be linearly related. Thus, the larger the pig house or the more animals per labour unit, the longer the fattening period and the higher the mortality rate. Within the total population about 4-5 p. 100 of the variation is cxplained by the applied linear model, whereas for pig houses without heating facilities $(\mathrm{NH})$ and piggeries with heating unit with fan suspended (FH) up to $50 \mathrm{p} .100$ of the variation can be explained. With regard to the emergency slaughter rate, differences were also related to the type of pig house. Apparently, heating facilities can be complementary to labour input in improving the production results.

\section{TABLE 2}

Correlation coefficients $(P<0.05)$ between building characteristics and production parameters.

Coefficients de corrélation $(P<0,05)$ entre les caractéristiques de construction et de régulation du climat des porcheries et les paramètres de production.

\begin{tabular}{|c|c|c|c|c|c|}
\hline & Total $(\mathrm{n}=81)$ & $\mathrm{FH}(\mathrm{n}=15)$ & $\mathrm{NH}(\mathrm{n}=20)$ & $R F(n=22)$ & $\mathrm{CR}(\mathrm{n}=19)$ \\
\hline - SA-LFP & 0.265 & - & - & 0.587 & 一 \\
\hline$-\mathrm{MR}$ & 0.215 & 0.740 & 0.536 & 一 & 一 \\
\hline - VO-LFP & 0.228 & - & - & 0.422 & - \\
\hline - MR & 0.196 & - & 0.516 & - & - \\
\hline - FCR & - & 一 & - & 0.640 & - \\
\hline - SS-MR & 0.317 & $\ldots$ & 0.531 & - & - \\
\hline - LFP & $\ldots$ & 0.712 & - & - & - \\
\hline - TCR-FCR . & 0.268 & 0.583 & 一 & 0.578 & - \\
\hline - TCW-ESR .. & 一 & 0.606 & - & - & 0.689 \\
\hline$-W G \ldots \ldots$ & - & - & 0.643 & - & -0.500 \\
\hline - NA-LFP $\ldots$ & 0.314 & 0.739 & - & - & 一 \\
\hline- MR $\ldots \ldots$ & 0.276 & - & - & - & - \\
\hline- FCR $\ldots \ldots$ & - & $一$ & - & 0.616 & 一 \\
\hline - ESR & - & $\ldots$ & - & 0.450 & 一 \\
\hline
\end{tabular}

$\mathrm{n}$ : number of piggeries - nombre de porcheries.

With respect to the evaluation of the influence of the slat surface (SS), an interaction with the heating system is observed concerning the variability of the mortality rate (MR), and the length of the fattening period (LFP). A comparable differential effect was found when comparing the ventilation system. Because of the application of large ventilation rates within mechanical ventilated piggeries, and the allied problem of controlling the air flow patterns within large pig units, most of the relationships were found within this classification.

\section{B. Feed conversion rate and weight gain}

The variation of feed conversion ratio (FCR) was partly explained by the variation of the thermal conductivity of the roof (TCR). In addition the variation of weight gain (WG) was also partly correlated to the thermal conductivity of the walls (TCW). Possibility variations of wall and roof temperature are at the origin 
of asymetric radiant fields co-determining thermal comfort (FANGER, 1970). Both relationships were however only explained within the same two pig house classifications, confirming the interaction between the heating system and the building characteristics with respect to the production results. Because of the occurrence of rather low ventilation rates, a beneficial effect of the thermal conductivity of the walls (TCW) on weight gain was found within the pig house with covered open ridge (CR).

- Correlation coefficients $(P<0.05)$ between building characteristics, production parameters and investigation results of the period from February 1982 to January 1983 (Table 3).

\section{a) Mortality rate and length of the fattening period :}

With respect to mortality rate (MR) and the length of the fattening period (LFP), the relationships with the surface area (SA), the volume of the pig house (VO) and the number of animals (NA) confirmed the previous observations.

\section{b) Tail biting :}

The variation of the occurrence of tail biting is partly explained by the following relationships as such, and probably by their interactions as well. A negative relationship of the total available space (SA, VO) with tail biting (PT) is observed. This may be explained by the possibility of the occurrence of lower levels of gaseous concentrations (KALICH, 1980 ; VAN PUTTEN, 1970), within larger buildings even when lower ventilation rates are applied, and/or because of a crowding of the pigs increasing the agressive behavioural pattern (LINDQuIST, 1974 ; RANDOLPH et al., 1981). Also a relationship with the availability of the feed is found, the casier the access to the feed, the higher the feed intake (AF versus FI) and the lower the occurrence of tail biting (PT versus AF), but with a higher possibility of feed wastage (AF versus FCR). But the latter was not measured. Impaired access to the feed can result in a dietary deficiency with respect to the components of the feed (MickwITz, 1970).

A positive relationship of tail biting (PT) with the inside temperature (IT) was observed for the whole population, and especially within pig houses with central heating $(\mathrm{CH})$ (too much heating?) or without heating (NH) (smaller pig houses with too less ventilation?) (FARGE et al., 1981).

\section{Other parameters}

Within the whole population, a positive relationship was found between internal temperature (IT) and emergency slaughter rate (ESR), and between air velocity at the height of the pigs (AV) and the number of pens with growth-retarded animals (PG). These results agree with the propositions concerning the influence of the air velocity (Close et al., 1981; MounT et al., 1980). But these relationships are not in accordance with the results of Texier et al. (1979), probably as a result of the interaction with the internal temperature, which was not always above $20^{\circ} \mathrm{C}$.

The importance of the regulation of the air inlet (RI) was indicated by the correlation coefficients with the number of pens when coughing occurred (PC), the number of pens with dirty laying areas (PL), the length of the fattening period (LFP), the emergency slaughter rate (ESR), the weight gain (WG) and the feed intake (FI). 
TABLE 3

Correlation coefficients $(P<0.05)$ between building characteristics, production parameters and investigation results (February 1982 to January 1983).

Coefficients de corrélation $(P<0,05)$ entr les caractéristiques de construction et de régulation du climat des porcheries, les paramètres de production et les résultats de l'enquête.

\begin{tabular}{|c|c|c|c|c|c|c|}
\hline & $\mathrm{T}(\mathrm{n}=86)$ & $\begin{array}{c}\mathrm{FH} \\
(\mathrm{n}=15)\end{array}$ & $\begin{array}{c}\text { PH } \\
(\mathrm{n}=13)\end{array}$ & $\begin{array}{c}\mathrm{NH} \\
(\mathrm{n}=20)\end{array}$ & $\begin{array}{c}\mathrm{RF} \\
(\mathrm{n}=21)\end{array}$ & $\mathrm{CR}(\mathrm{n}=19)$ \\
\hline - SA-MR $\ldots$ & 0.281 & - & - & 一 & - & - \\
\hline$-\mathrm{PC} \ldots \ldots$ & -0.222 & - & - & 一 & 一 & - \\
\hline$-\mathrm{PT} \ldots \ldots$ & -0.334 & - & 一 & - & - & - \\
\hline$-P G$ & - & 一 & - & 一 & 0.519 & - \\
\hline - LFP & - & 0.526 & 一 & 0.702 & - & 一 \\
\hline - VO-MR & 0.269 & - & 一 & - & - & 一 \\
\hline$-\mathrm{PT} \ldots \ldots \ldots$ & -0.273 & - & - & - & 一 & 一 \\
\hline$-P G$ & - & - & 一 & - & 0.485 & - \\
\hline - SS-WG $\ldots$ & -0.291 & -0.576 & 一 & - & - & - \\
\hline - FCR. & - & - & - & - & - & 0.610 \\
\hline - MR & - & - & 一 & - & 一 & 0.558 \\
\hline - ESR & - & - & - & - & - & 0.797 \\
\hline$-\mathrm{CV} \mathrm{I} \ldots \ldots$ & -0.273 & - & - & -0.430 & - & 一 \\
\hline- CV III ... & 0.302 & 一 & - & 0.513 & - & - \\
\hline$-\mathrm{CV} E \ldots$ & - & - & - & - & -0.474 & 一 \\
\hline - IT-PT $\ldots$. & 0.272 & 一 & 一 & 0.568 & 一 & 一 \\
\hline - ESR & 0.256 & - & - & - & - & - \\
\hline - AV-PG & 0.222 & - & 一 & 一 & - & 一 \\
\hline - RI-PC. & -0.250 & 一 & - & - & - & 一 \\
\hline - PL $\ldots$ & -0.425 & 一 & - & — & - & - \\
\hline - LFP... & 0.351 & 一 & - & 0.522 & - & - \\
\hline - RI-ESR & -0.269 & - & $\ldots$ & - & - & 一 \\
\hline - WG . . & 0.313 & 一 & - & 0.543 & - & 一 \\
\hline$-\mathrm{FI}$ & 0.336 & - & - & 0.636 & - & - \\
\hline - PC-PG & 0.296 & 一 & - & 0.504 & - & 一 \\
\hline$-\mathrm{CV} \mathrm{E}$ & - & - & -0.570 & - & - & - \\
\hline$-\mathrm{CV}$ III & 一 & 一 & 0.548 & - & - & 一 \\
\hline - PT-AF & -0.269 & 一 & 一 & - & - & - \\
\hline - FCR . & -0.226 & 一 & -- & - & - & 一 \\
\hline - PD .. & 0.561 & - & - & 一 & - & - \\
\hline - AF-FCR & 0.278 & 一 & - & - & - & - \\
\hline- FI $\ldots$. & 0.281 & - & - & - & - & 一 \\
\hline - NA-MR & 0.319 & - & - & - & - & 一 \\
\hline - WG-FCR .. & -0.428 & - & -- & 一 & - & 一 \\
\hline$-\mathrm{CVE} \ldots \ldots$ & 0.275 & 一 & - & - & 一 & - \\
\hline$-\mathrm{CV} \mathrm{IV}$ & 0.503 & - & - & 0.552 & - & - \\
\hline
\end{tabular}


Although the frequency of regulation is not necessarily an indication of a good regulation, the results correspond with the concept of the importance of an automatic regulation of the ventilation system (air inlet and outlet) not only to obtain the proposed temperature, but also with respect to the airflow pattern and the air velocity taking into account the behavioural pattern of the animals (RANDALL \& BATTAMS, 1979 ; RANDALL \& ARMSBY, 1983 ; Randall et al., 1983 a, b). Animals suffering from coughs $(P C)$ tended to grow slower $(P G)$, especially in unheated piggeries $(\mathrm{NH})$, as mentioned by Truyen (1977) and TIELEN (1977). But again, the interaction with the heating system was significant. The carcasses of these animals fattened in piggeries with pipes heaters $(\mathrm{PH})$ had a lower commercial grade. This may have arisen from a too low heating capacity in combination with too high ventilation rates resulting in internal temperatures being too low when starting the fattening period. Thus compensatory feed intake may have occurred, resulting in fatter carcasses (VERSTEGEN at al., 1982).

TABLE 4

Mean with standard deviation $(M \pm s . d$.

of some parameters and their correlation coefficients $(r)$

with the occurrence of cough and dirty laying area in piggeries with compartments.

Moyenne avec écart-type ( $M \pm s . d$.) de quelques paramètres, et coefficients de corrélation ( $r$ ) avec la fréquence de toux et d'emplacement sale dans les porcheries compartimentées.

\begin{tabular}{|c|c|c|c|c|}
\hline $\mathbf{M} \pm$ s.d. & $\mathrm{T}(\mathrm{n}=124)$ & $P(n=55)$ & $D(n=54)$ & $C(n=24)$ \\
\hline $\mathrm{OT}^{\circ} \mathrm{C}$ & $15.7 \pm 4.61$ & $14.7 \pm 3.21$ & $17.4 \pm 5.59$ & $13.3 \pm 2.71$ \\
\hline $\mathrm{CT}^{\circ} \mathrm{C}$ & $16.1 \pm 3.83$ & $15.7 \pm 2.19$ & $17.2 \pm 4.92$ & $13.7 \pm 2.06$ \\
\hline IT ${ }^{\circ} \mathrm{C}$ & $21.6 \pm 2.76$ & $21.0 \pm 1.77$ & $22.6 \pm 3.54$ & $20.5 \pm 1.14$ \\
\hline AI cm & $9.53 \pm 8.81$ & $9.32 \pm 8.08$ & $11.0 \pm 9.87$ & $3.92 \pm 4.08$ \\
\hline $\mathrm{r}(\mathrm{P}<0.05)$ & & & & \\
\hline - OT-CT & 0.898 & 0.663 & 0.936 & 0.899 \\
\hline - IT . . & 0.721 & 一 & 0.828 & 0.716 \\
\hline- PL $\ldots \ldots \ldots$ & 0.308 & - & - & - \\
\hline$-\mathrm{PC} \ldots \ldots \ldots$ & -0.256 & - & -0.343 & - \\
\hline - CT-IT & 0.808 & 0.446 & 0.865 & 0.784 \\
\hline- PL $\ldots \ldots \ldots$ & 0.263 & - & - & 一 \\
\hline$-\mathrm{PC}$ & -0.285 & - & -0.295 & - \\
\hline — IT-PL & 0.328 & - & 一 & 一 \\
\hline - PC . & -0.198 & - & -0.283 & - \\
\hline — AI-PL & 0.242 & - & - & - \\
\hline - PC. & -0.245 & - & -0.281 & 一 \\
\hline
\end{tabular}

Working unit : compartment - Unité d'observation : le compartiment.

$\mathrm{T}$ : total population - population totale.

$\mathbf{P}$ : no cough, no dirty laying area - pas de totix, pas d'emplacement sale.

$\mathrm{D}$ : at least one dirty laying area - au moins une loge avec emplacement sale.

$\mathrm{C}$ : at least one pen with cough - au moins une loge avec toux.

$\mathrm{n}$ : number of cases - nombre de cas. 
Fast growing animals (WG) tended to realize a lower feed conversion ratio (FCR), but were classified in the high and the low carcass grades (CV) as well. Hence, interactions with the genotype (lean, fat type) are proposed to explain these results.

Besides the interactions of the building characteristics with the heating system, the interaction with the ventilation system was also shown. Due to the overriding effect of the ventilation rate within mechanical ventilated piggeries (RV) only a relationship with surface area (SA) and house volume (VO) was found. Hence, within the piggeries with natural ventilation (RC) and which had lower ventilation rates, variations with respect to slat surface (SS) could become significant.

- Correlation coefficients between some building characteristics of pig houses with compartments, inside climatic conditions and the occurrence of cough and dirty laying areas (investigation period from April to July 1983) (Table 4).

Comparing with the P-population (Table 4), the C- and D-populations showed statistically significant differences $(\mathrm{P}<0.05)$ with respect to the outside (OT), the corridor (CT) and the inside (IT) temperature. Cough and dirty laying area occurred simultaneously, but the proportion depended on the absolute value of the temperature and the opening of the air inlet (AI). Indeed, taking into account the mean value with standard deviation of $\mathrm{AI}$, and in connection with the results mentioned above, we can conclude that within the $\mathrm{C}$-population the air inlet was insufficiently regulated with respect to the outside conditions. Hence, when also taking into account the larger difference between incoming and inside temperature in combination with a smaller inlet opening or a possibly higher air velocity, draught can be at the origin of the occurrence of cough and/or dirty laying area (TRUYEN, 1977).

\section{Conclusions}

By means of the linear regression analysis and of their correlation coefficients. it was possible to show what proportion of the variance of production parameters may be attributed to the variance of building characteristics and the engineering and control systems of the environment as well.

Within the total population about $4-5$ p. 100 of the variance of production parameters was explained by the physical characteristics of the pig house, whereas within classification of the different engineering and control systems the explained proportion could be ten times larger. Although a selection of pig houses was made with a view to homogenize and to distribute at random production determining factors such as stockmanship, it was interesting to find on the one side relationships through the remaining variance of stockmanship, whereas on the other hand an interaction between the level of stockmanship and the engineering and control systems was shown. This is an additional factor within the complex of the production determining factors.

Within the limitations of our project, no deviations from the proposed optimal environmental temperature (CLOSE, 1981 ; VerstegEN, 1971), were observed. Hence, the occurrence of coughing and dirty lying area when the pigs are in their thermal neutrality zone indicate that in the case of the Belgian Landrace pigs environmental 
control based on the lower critical temperature alone, even when the animals use the hudling mechanism (BooN, 1981), is not sufficiently adequate. With respect to the regulation of the air inlet, determining the air flow pattern and air velocity at the level of the pigs, an automatically controlled ventilation system seems necessary to cope with the continuously changing outside climatic conditions through the stockmanship of the farmers. Hence, an outside-independent and stabilized ventilation pattern, including a temperature and air velocity gradient across the pens has to be possible (RANDall \& ARMSBY, 1983 ; Randall et al., 1983 a, b). Or within certain limits, the individual pig can choose his prefered environment, which is stabilized in time, and so its behaviour pattern as well.

\section{Résumé \\ Des relations entre les caractéristiques de construction et de régulation du climat des porcheries et les résultats de production}

Dans le but d'expliquer les variations des paramètres en rapport avec la croissance, l'efficacité alimentaire et le taux de mortalité, les relations avec les caractéristiques de construction et de régulation du climat des porcheries ont été examinées. La méthode de collecte des données concernant les porcheries sous contrat (effectif : 97 étables; conduite en bande avec vide sanitaire), a permis une distribution homogène et aléatoire des autres facteurs : génétiques, alimentation, engraisseur.

Les variations du taux de mortalité et de la période de croissance sont expliquées par la variation de la surface et l'effectif de la porcherie. Plus la porcherie est grande, plus l'effectif de porcs présents est élevé, plus longue est la période de croissance et plus élevé est le taux de mortalité, particulièrement si le chauffage est insuffisant. Pour ce qui concerne l'efficacité alimentaire et le gain de poids une interaction identique est trouvée avec la conductivité thermique du toit et des murs. Des effets différentiels et comparables étaient aussi observés dans l'analyse des systèmes de ventilation. Les relations se situent surtout dans la classification des porcheries avec une ventilation dynamique.

La fréquence du cannibalisme était en partie expliquée par la variation de l'espace disponible et par la variation de la température dans la porcherie. Les porcs atteints de toux, ont une vitesse de croissance plus faible et la valeur des carcasses est moindre. Le coefficient de corrélation était positif pour la relation entre la vitesse de l'air au niveau du porc et la fréquence des porcs ayant un retard de croissance. Alors, l'importance de la régulation de l'entrée de l'air devient évidente, car l'aménagement des porcheries, en ce qui concerne la ventilation, détermine la vitesse et le type de circulation de l'air.

Les porcs qui ont tendance à avoir une efficacité alimentaire meilleure, présentent des carcasses dont le classement est variable.

L'analyse des coefficients de corrélation montre qu'une grande proportion de la variance des paramètres de production est expliquée par la variation des caractéristiques de construction et de régulation du climat des porcheries. Mais outre les recommandations relatives au milieu physique, on doit tenir compte du comportement des animaux et veiller à la prévention des problèmes sanitaires, si l'on désire améliorer les résultats de production.

Mots clés : environnement, porc en croissance, production porcine, logement, ventilation.

Reçu en novembre 1983.

Accepté en septembre 1984.

\section{Acknowledgements}

The authors thank the \&Instituut voor Wetenschappelijk Onderzoek in Nijverheid en Landbouw» and the «Belgische Boerenbond - A.V.V. » for their financial support. R. Geers was supported by the «Nationaal Fonds voor Wetenschappelijk Onderzoek». 


\section{References}

Boon C.R., 1981. The effect of departures from lower critical temperature on the group postural behaviour of pigs. Anim. Prod., 33, 71-79.

CLOSE W.H., 1981. The climatic requirements of the pig. In : Environmental aspects of housing for animal production (Ed. by CLARK J.A.), Butterworths, London, pp. 149-166.

Close W.H., Heavens P.P., Brown D., 1981. The effects of ambient temperature and air movement on heat loss from the pig. Anim. Prod., 32, 75-84.

FANGer P.O., 1970. Thermal Comfort. Analysis and applications in environmental engineering. McGraw-Hill, New York, 244 p.

Farge B. De La, Granier R., Texier C., 1981. Les conditions de ventilation en porcherie d'engraissement : effets du débit et de vitesse de l'air. $13^{\text {es }}$ Journées de la Recherche porcine en France, 27-38, I.N.R.A. - I.T.P. ed., Paris.

Geers R., Berckmans D., Goedseels V., Wijnhoven J. \& Maes F., 1984 a. A case-study of fattening pigs in Belgian contract farming. Mortality, efficiency of food utilization and carcass value of growing pigs in relation to environmental engineering and control. Anim. Prod., 38, 105-111.

Geers R., Goedselels V., Berckmans D., Huybrechts W., 1984 b. Effect of season and environmental control on mortality and feed conversion ratio of pigs. Livest. Prod. Sci., 11, 235-241.

Kalich J., 1980. Harmful gases in the piggery air and its influence on the fattening performance of pigs. Tierzüchter, 32, 386-388.

LINDQVIST J., 1974. Animal health and environment in the production of fattening pigs. Acta Vet. Scand. Suppl. 51, 78 p.

Mickwitz G. Von, 1970. Fortbildungskursus für Schweinekrankheiten. Prakt. Tierartz, 51, 589-590.

Mount L.E., 1968. The climatic physiology of the pig. Arnold, London, $271 \mathrm{p}$.

Mount L.E., Start I.B., Brown D., 1980. A note on the effects of forced air movement and environmental temperature on weight gain in the pig after weaning. Anim. Prod., 30, 295-298.

Randall J.M., BatTams V.A., 1979. Stability criteria for airflow patterns in livestock buildings. J, agric. Engng Res., 24, 361-374.

Randall J.M., ARMSBy A.W., 1983. Cooling gradients across pens in a finishing piggery. I. Measured cooling gradients. J. agric. Engng. Res., 28, 235-245.

Randall J.M., Armsby A.W., Sharp J.R., 1983 a. Cooling gradients across pens in a finishing piggery. II. Effects on excretory behaviour. J. agric. Engng. Res., 28, 247-259

Randall J.M., Sharp J.R., Armsby A.W., 1983 b. Cooling gradients across pens in a finishing piggery. III. Effects on performance and health. J. agric. Engng. Res., 28, 261-268.

Randolph J.H., Cromwell G.L., Stahly T. \& Kratzer D.D., 1981. Effects of group size and space allowance on performance and behaviour of swine. J. Anim. Sci., 53, 922-927.

Stolpe J. \& BREsk B., 1979. Wechselnde Temperaturen in der Mastschweinehaltung. Monatshefte für Veterinarmedizin, 34, 337-340.

Texier C., Farge B. De La \& Granier R., 1979. Influence des variations des principaux facteurs de l'ambiance en porcherie d'engraissement. $11^{\text {cs }}$ Journées de la Recherche porcine en France, 19-20, I.N.R.A., I.T.P. ed., Paris.

Texier C., Granier R. \& Farge B. De La, 1981. Comparaison de quatre systèmes de ventilation en porcherie d'engraissement. $13^{\text {es }}$ Journées de la Recherche porcine en France, 17-25, I.N.R.A.-I.T.P. ed., Paris.

Tielen M.J.M., 1977. Stallklima und Tiergesundheit auf Schweinemastbetrieben. Arbeitstagung der internationale Gesellschaft für Tierhygiene, 5-7 September 1977, Krakow, 20 p. 
TRUYEN W.T., 1977. Stallklima, Hygiene und Tiergesundheit auf Schwcinezuchtbetrieben. Arbeitstagung der internationale Gesellschaft fïr Tierhygiene, 5-7 September 1977, Krakow, 17 p.

Van PutTen G., 1970. Analyse und Vorbeugen des Schwanzbeissens bei Mastschweinen. Dtsch. Tierärtzl. Wschr., 77, 134-135.

VERSTEGEN M.W.A., 1971. Influence of environmental temperature on energy metabolism of growing pigs, housed individually and in groups. Meded. Landbouwhogeschool Wageningen, 71 (2), $115 \mathrm{p}$.

Verstegen M.W.A., Brandsma H.A. \& Mateman G., 1982. Feed requirement of growing pigs at low environmental temperatures. J. Anim. Sci., 55, 88-94.

Wahlstrom R.C., 1981. Effect of housing systems on growing pigs. Pigs News \& Inf., 2, 271-274. 